Investments (par value $\$ 8,500.00) \ldots \ldots \ldots \ldots . \ldots 8,259.50$

Balance in First National Bank (Ithaca) ...... 894.08

The Life Membership Fund now amounts to $\$ 4,800.82$.

VIRGIL SNYDER, Acting Treasurer.

ITHACA, N. Y.,

December 23, 1913.

\title{
REPORT OF THE AUDITING COMMITTEE
}

The undersigned Auditing Committee, appointed by the American Mathematical Society, have this day examined the accounts of the Treasurer, compared them with the vouchers, bank-book, and securities, and find the following to be correct:

Balance from December 21, $1912 \ldots \ldots \ldots \ldots \ldots \ldots \ldots \ldots \ldots$. . . . . 684.92

Cash receipts since December $21,1912 \ldots \ldots \ldots \ldots \ldots \ldots \ldots, 132.02$

Balance in First National Bank (Ithaca) ......\$894.08

$\overline{\$ 15,816.94}$

Investments (par value $\$ 8,500.00) \ldots \ldots \ldots \ldots . \ldots .259 .50$

Disbursements since December 21, $1912 \ldots \ldots \ldots 6,663.36$

J. H. M. WedDERBURN,

H. E. HAwKES, Auditing Committee.

NEw YoRK, N. Y.,

December 23, 1913. 